\title{
Role of the Criminal Law in Maintaining Hong Kong as an International Financial Centre
}

\author{
Simon N.M. Young*
}

\begin{abstract}
While criminal law is an essential part of the legal environment used to maintain Hong Kong's status as an international financial centre (IFC), its role is limited. Criminal law and processes are reserved for serious cases that involve the protection of property rights, economic interests, or the integrity of the financial system. Deterrent and remedial civil processes are increasingly being used as a more effective way to enforce law designed to maintain Hong Kong's IFC status.
\end{abstract}

Keywords: Hong Kong International Financial Centre, White Collar Crime, Financial Crime, Securities Law Enforcement, Criminal and Civil Sanctions

\section{Introduction}

The Hong Kong government is constitutionally required to "provide an appropriate economic and legal environment for the maintenance of the status of Hong Kong as an international financial centre". ${ }^{1}$ The criminal law is an essential part of that legal environment. But what precise role does it play in maintaining an international financial centre (IFC). Too much criminal law can restrict freedom of contract, breed inefficiencies, and become a tool for the powerful to oppress the weak. Too little criminal law would allow the dishonest to wreck havoc on the marketplace and take advantage of investors and others. There needs to be a proper balance of criminal and non-criminal laws to enforce and regulate financial systems without unduly impairing economic growth and competition.

This chapter discusses the role of criminal law in maintaining Hong Kong's status as an IFC. The underlying criminal law framework can be organised into two broad categories: (i)

\footnotetext{
* Professor and Associate Dean (Research), Faculty of Law, The University of Hong Kong. The author thanks Antonio Da Roza for his assistance. Contact: snmyoung@hku.hk

${ }^{1}$ Basic Law, Art. 109.
} 
offences that protect property rights and interests, and (ii) offences that safeguard the integrity of the financial system. The role of criminal law must be seen against a network of regulatory contexts governing financial markets, banks and other financial institutions, companies and individuals who participate in financial systems. Each regulatory regime has its own criminal and non-criminal measures to enforce the law and achieve regulatory aims. In this crowded field, criminal law plays a limited but traditional role, to censure and punish harmful or serious misconduct. It also plays an important secondary role of providing teeth to the numerous powers and duties that promote more disclosure and transparency in the market place.

\section{Use of the Criminal Sanction}

Every society has criminal laws to protect its most basic moral values. As societies become more developed, criminal laws are used to protect and realise important societal aims and purposes. The criminal laws used in maintaining Hong Kong's IFC status are of two kinds. The first are those that protect individual property rights and economic interests. These offences are mainly found in the Theft Ordinance, ${ }^{2}$ which was largely migrated from the English Theft Acts of 1968 and 1978. ${ }^{3}$ Other similar offences can be found in specific legislation such as those that relate to companies and insolvency. The second kind is a broader category. These laws are concerned with maintaining the integrity of financial systems. Such integrity is measured by people's confidence in the system. Confidence is affected by behaviour that distorts the level playing field in the marketplace, promotes the movement of illegal assets, or induces conflicts of interest. Where such conduct poses a serious risk to public confidence in financial systems, interdiction by the criminal law is required. Illustrative offences of both these types are described more fully below.

\section{A. Protecting Property Rights and Economic Interests}

\section{General Offences}

\footnotetext{
2 Theft Ordinance (Cap. 210).

${ }^{3}$ Jackson (2003), p. 727.
} 
The Theft Ordinance revised "the law as to theft and similar or associated offences" by abolishing common law crimes and consolidating relevant offences under a single statute. ${ }^{4}$ Two offences explicitly protect "property belonging to another". The classic offence of "theft" is defined as the dishonest appropriation of property belonging to another with the intention to permanently deprive the other of it. $^{5}$ Appropriation has a broad meaning. It includes an "assumption by a person of the rights of an owner" and also the situation where a person comes "by the property (innocently or not) without stealing it" and later assumes a right to it "by keeping or dealing with it as owner". ${ }^{6}$ Following English case law, there is an appropriation even if property is taken with the consent of the owner; what matters is whether the appropriation was dishonest. ${ }^{7}$ Property, also defined broadly, includes "money and all other property, real and personal, including things in action and other intangible property". ${ }^{8}$ The other offence that protects property belonging to another is "obtaining property by deception", one of several offences designed to deal with frauds. It is committed when a person "by any deception (whether or not such deception was the sole or main inducement) dishonestly obtains property belonging to another, with the intention of permanently depriving the other of it". 9

Other offences in the Theft Ordinance protect broader proprietary or economic interests. The statutory offence of "fraud" involves intentional deceit inducing a person to act (or omit to act) that results in benefit to another person or "prejudice or a substantial risk of prejudice" to a person other than the offender. ${ }^{10}$ Prejudice is defined as "any financial or proprietary loss, whether temporary or permanent". "There are other offences that prohibit the use of deception to obtain "pecuniary advantages", obtain "services", evade liability, or procure an entry in certain records. ${ }^{12}$ Two offence sections are directed towards protecting the economic interests of investors and creditors. They are the offences of false accounting and publishing false statements by company directors. ${ }^{13}$ While there are many cases of false accounting, one of the more famous cases involved the prosecution of the chairman and financial controller of

\footnotetext{
${ }^{4}$ Theft Ordinance, long title.

${ }^{5}$ Ibid., s. 2(1) [liable to 10 years imprisonment].

${ }^{6}$ Ibid., s. 4(1).

${ }^{7} R v$ Hinks [2001] 2 AC 241 (HL), applied in HKSAR v Wong Cho Sum [2001] 3 HKLRD 76, [34]-[35] (CA); HKSAR v Woo Mei Bo Mable, unreported, CACC565/2002, 15 Aug 2003, CA, [98].

${ }^{8}$ Theft Ordinance, s. 5(1). For a case involving theft of a chose in action, see HKSAR v Wong Cho Sum, ibid.

${ }^{9}$ Ibid., s. 17(1) [liable to 10 years imprisonment].

${ }^{10} \mathrm{Ibid}$., s. 16A(1) [liable to 14 years imprisonment].

${ }^{11}$ Ibid., s. 16A(3).

${ }^{12}$ Ibid., ss. 18, 18A, 18B, 18D, respectively.

${ }^{13}$ Ibid., ss. 19, 21, respectively.
} 
the multi-billion dollar conglomerate Allied Group for misrepresenting large share placements by independent investors when in fact the shares were issued to connected companies. $^{14}$

There is a provision in the Theft Ordinance that extends criminal liability to company officers where the company is proved to have committed certain offences. ${ }^{15}$ Directors, managers, secretaries or similar officers of the company will also be guilty of any corporate offences committed with that individual's "consent or connivance". ${ }^{16}$ In practice, provisions of this kind have little impact because of the stringent requirements for proving corporate criminal liability. ${ }^{17}$ Such liability requires that the directing mind and will of the company have the mens rea for the offence, and thus it becomes superfluous to speak of whether the directors had consented or connived in the offence. The requirement of "consent or connivance" would only add something more if the offence committed by the company was one involving strict or absolute liability. ${ }^{18}$

A common thread that runs through many of the offences discussed here is the element of dishonesty. ${ }^{19}$ As interpreted by courts, this is an important mental element ensuring that only persons with moral culpability will be convicted. Dishonesty "describes a state of mind [...] consisting of both objective and subjective elements". ${ }^{20}$ Dishonesty means that, by ordinary standards of reasonable and honest people, the defendant's conduct was dishonest, and the defendant "realised that what he was doing was by those standards dishonest". ${ }^{21}$ Thus the element does not simply ask if the defendant believed his actions were honest; the question is asked with reference to the objective standard.

Fraud offences have the additional element that either deceit or deception was used. ${ }^{22}$ This element is defined broadly and includes any deceit or deception "(whether deliberate or

\footnotetext{
${ }^{14}$ Young (2006).

${ }^{15}$ Theft Ordinance, s. 20(1), applying only to offences committed by a "body corporate under section 17, 18, $18 \mathrm{~A}, 18 \mathrm{~B}, 18 \mathrm{D}, 19$ or $22(2) "$.

${ }^{16}$ Ibid., s. 20(1).

${ }^{17}$ Hong Kong still applies the English identification doctrine as set down in Tesco Supermarket Ltd $v$ Nattrass [1972] AC 153 (HL). See HKSAR v Telephone Est (HK) Company Ltd [2014] 1 HKC 197 (CFI); The Queen v Lee Tsat Pin, unreported, CACC315/1985, 19 Dec 1985, CA, [20].

18 See e.g. Securities and Futures Commission v C.L. Management Services Limited, unreported, ESS3067/2013, 11 June 2014, Mag Crt, [52].

${ }^{19}$ Common to offences in Theft Ordinance, ss. 2, 15-18, 18A-18D, 19, 22, 24.

${ }^{20}$ Mo Yuk Ping v HKSAR (2007) 10 HKCFAR 386, [45]-[46].

${ }^{21} R v$ Ghosh [1982] QB 1053, 1064 (CA), recognised as the position adopted in Hong Kong in Chan Fat Chu Raymond $v$ HKSAR (2009) 12 HKCFAR 775, [49] and Mo Yuk Ping v HKSAR, ibid., [51]. (Emphasis added)

${ }^{22}$ Statutory fraud in s. 16A of the Theft Ordinance has the element of deceit. Other offences in ss. 17, 18, 18A, $18 \mathrm{~B}, 18 \mathrm{D}, 22$ require proof of deception.
} 
reckless) by words or conduct (whether by any act or omission) as to fact or as to law, including a [deceit/deception] relating to the past, the present or the future and a [deceit/deception] as to the intentions of the person [using the deception or practicing the deceit] or any other person". 23

Another important offence is the common law offence of conspiracy to defraud. In 1999, at the strong urging of the Administration, legislators decided to retain this common law offence, even though all other common law conspiracies had been abolished and a new statutory offence of fraud was being enacted. ${ }^{24}$ Government lawyers argued that retaining this long-established and broad offence was desirable in case there were gaps in the statutory offence and also to meet the double criminality requirement in extradition requests to and from places that also had the offence. ${ }^{25}$ In Mo Yuk Ping $v$ HKSAR, the Court of Final Appeal (CFA) considered the elements of this offence and found them to be in compliance with constitutional requirements of legal certainty. ${ }^{26}$ This case involved artificial trading in a stock in order to maintain its price and avoid default on a loan. The common law offence is committed when two or more persons agree to "use dishonest means to cause economic loss to another or to put at risk another's economic interests". ${ }^{27}$ The test for dishonesty is the "two-stage" Ghosh test, which is the same as the one used in theft and other offences. ${ }^{28}$ In addition to economic loss, the offence also extends to means that induce persons to act "contrary to public duty", thereby serving as an important tool in corruption cases. ${ }^{29}$ In upholding the need for this broad offence, Sir Anthony Mason NPJ wrote,

It has been widely recognized that there is no limit to the ingenuity of fraudsters in engineering novel means of defrauding others. This ingenuity leads to the conclusion that the enactment of specific offences is not an adequate safeguard unless they are accompanied by a general offence. ${ }^{30}$

\footnotetext{
${ }^{23}$ Ibid., s. 17(4).

${ }^{24}$ The Law Reform Commission of Hong Kong had recommended its abolition in 1996 (see LRCHK (1996), [5.48]), but the Administration convinced legislators to retain it in 1999 (see LegCo Secretariat (1999), [27]). See also Theft Ordinance, s. 16A(4); Crimes Ordinance (Cap. 200), s. 159E(2). Conspiracy to defraud is punishable up to 14 years imprisonment (Crimes Ordinance, s. 159C(6)).

${ }^{25}$ Legal Policy Division (1998), p. 2.

${ }^{26}$ Mo Yuk Ping $v$ HKSAR, supra note 20.

${ }^{27}$ Ibid., [40] \& [55].

${ }^{28}$ Ibid., [55].

${ }^{29}$ Ibid.

${ }^{30}$ Ibid., [63].
} 
Given the increased use of the Internet to handle financial transactions, police are making greater use of a general computer-related offence known as "unlawful access to a computer". ${ }^{31}$ The offence is committed if a person obtains access to a computer with one of four possible states of mind: (a) with intent to commit an offence; (b) with a dishonest intent to deceive; (c) with a view to dishonest gain for himself or another; or (d) with a dishonest intent to cause loss to another. ${ }^{32}$ In one case, a Merrill Lynch private wealth manager was convicted of this offence for creating loans in client accounts without the client's knowledge or authorisation. ${ }^{33}$

\section{Offences in Specific Legislation}

While the offences in the Theft Ordinance are general enough to cover most situations, there are also offences protecting property rights and interests in specific regulatory legislation. In the company law context, there are offences for the making of false statements, ${ }^{34}$ issuing prospectuses containing untrue statements, ${ }^{35}$ and destroying documents filed in the Company Registrar's office "with a view to gain [...] or with intent to cause loss to another" ${ }^{36}$ When companies become insolvent and are wound up, there are offences to protect creditors and investors. ${ }^{37}$ The more serious of these offences include knowingly being party to a business of a company carried on with intent to defraud creditors or for any fraudulent purpose, ${ }^{38}$ company officer disposing of property obtained on credit within 12 months of the winding up, ${ }^{39}$ and frauds by officers of companies which have gone into liquidation. ${ }^{40}$

\section{B. Safeguarding the Integrity of Financial Systems}

\footnotetext{
${ }^{31}$ Crimes Ordinance, s. 161(1) [liable to 5 years imprisonment].

${ }^{32}$ Ibid.

${ }^{33}$ HKSAR v Hsu Ming Mei [2013] 1 HKLRD 286 (CA).

${ }^{34}$ Companies Ordinance (Cap. 622), ss. 895(1) [liable to 2 years imprisonment] \& 915 [liable to 6 months imprisonment].

${ }^{35}$ Companies (Winding Up and Miscellaneous Provisions) Ordinance (Cap. 32), ss. 40A(1) \& 342F(1) [liable to 3 years imprisonment]. For more, see Da Roza \& Tang (2014).

${ }^{36}$ Companies Ordinance, s. 65(1) [liable to 7 years imprisonment].

${ }^{37}$ Companies (Winding Up and Miscellaneous Provisions) Ordinance, Sch. 12.

${ }^{38}$ Ibid., s. 275(3) [liable to 5 years imprisonment].

${ }^{39}$ Ibid., s. 271(1)(o) [liable to 5 years imprisonment].

${ }^{40}$ Ibid., s. 273 [liable to 2 years imprisonment].
} 
Even before 1997, judges took into account Hong Kong's status and reputation as an international financial centre in its decisions. In a 1993 human rights challenge to the Securities and Futures Commission's (SFC) powers of investigation, the court noted: "Effective regulation is essential to the continuance of Hong Kong's economic prosperity as a commercial and international financial centre." ${ }^{41}$ Post-1997 decisions have made explicit reference to maintaining Hong Kong's IFC status in various contexts, including decisions to admit overseas counsel on an ad hoc basis, ${ }^{42}$ sentencing decisions, ${ }^{43}$ and decisions to order re-trial. $^{44}$

There are many criminal offences aimed at safeguarding the integrity of the financial system. These offences aim at maintaining the high repute of the system and ensuring public confidence in financial and legal institutions. While these offences are indirectly concerned with economic and proprietary interests, they are more directly concerned with preventing and punishing conduct that threatens to taint and impair the proper operation of financial systems and regulatory regimes. This chapter discusses three types of offences concerned respectively with the integrity of financial markets, the integrity of financial transactions, and the integrity of individuals in business and government.

\section{Insider Dealing and Other Market Misconduct}

The Securities and Futures Ordinance (SFO), enacted in 2002, was the product of a major law reform exercise that consolidated 10 different ordinances and introduced new changes. ${ }^{45}$ When the law was proposed, its stated aim was "to enshrine a user-friendly regulatory regime for the development of a fair, orderly and transparent market that is competitive internationally as well as attractive to investors, issuers and intermediaries." ${ }^{46}$ It was said to be a "modern legal framework" that "(a) promotes market confidence; (b) secures appropriate

\footnotetext{
${ }^{41}$ In Re Commission Ordinance, unreported, HCMP3039/1992, 8 Jan 1993, HC, [81].

${ }^{42}$ Re Robin Potts QC, unreported, HCMP4108/1999, 23 Sept 1999, CFI, [11], but see more recent decision in Re Timothy Michael Lord QC, unreported, HCMP1397/2013, 16 Aug 2013, CFI, [19].

${ }^{43}$ HKSAR v Hill Wong, unreported, CACC329/2006, 4 July 2007, [26]; HKSAR v Pike James Edward, unreported, CACC486/2006, 9 Aug 2007, CA, [32]-[33]; HKSAR v Boma Amaso [2012] 2 HKLRD 33, [31] (CA).

${ }^{44}$ HKSAR v Tarazona Edgar Henry, unreported, CACC508/2002, 21 May 2013, CA, [76].

${ }^{45}$ Securities and Futures Ordinance (Cap. 571), originally Ord. 5 of 2002, in force on 1 Apr 2003, L.N. 12 of 2003. See also Financial Services Bureau (2000), [5].

${ }^{46}$ Financial Services Bureau, ibid., [6].
} 
investor protection; (c) reduces market malpractice and financial crimes; and (d) facilitates innovation and competition". 47

Prior to the SFO, insider dealing was not treated as a criminal offence; there was only an offence of market misconduct. ${ }^{48}$ The SFO widened the scope of wrongdoing by introducing six types of market misconduct including insider dealing. ${ }^{49}$ Each type of market misconduct can be the subject of either criminal or civil proceedings, but no single set of facts can give rise to both. ${ }^{50}$ When the SFC proceeds by civil proceedings the case is brought before a Market Misconduct Tribunal, which holds oral hearings and has a wide range of powers to address any misconduct found. ${ }^{51}$ Pursuant to a 2007 agreement between the SFC and Prosecutions Division of the Department of Justice (DOJ), the SFC refers all potential market misconduct prosecutions to the DOJ, who decides whether the case should be prosecuted by the SFC in the magistrates' court or by the DOJ in the District Court or High Court. ${ }^{52}$ It is exceptional for the DOJ to delegate its prosecution authority in this way but it was done as an acknowledgement of the regulatory agency's expertise and commitment to enforcement. As explained below, the delegation has not been without difficulties.

Insider dealing has a technical definition under the SFO but is generally committed when a person connected with a listed corporation, knowing inside information about that corporation, deals in that corporation's listed securities or derivatives (or that of a related corporation). ${ }^{53}$ Counseling or procuring another person to deal in the corporation's listed securities or derivatives would also be insider dealing. ${ }^{54}$ Inside information is "specific information" about the corporation that is not generally known but would, if generally known to persons likely to deal in the security, materially affect the price of the security. ${ }^{55}$ Hong Kong courts take the offence of insider dealing quite seriously. In identifying the harm of insider dealing, the CFA referred to the threat it posed to the integrity of financial markets:

Insider dealing is an "insidious mischief" which threatens the integrity of financial markets and public and investor confidence in the markets. The object of [the

\footnotetext{
47 Ibid.

${ }^{48}$ SFC (2000), p. 4.

${ }^{49}$ Securities and Futures Ordinance, s. 245(1).

${ }^{50}$ Ibid., s. 252A(1), (3) \& (4).

${ }^{51}$ Ibid., Part XIII, Division 2.

${ }^{52}$ SFC (2013b).

${ }^{53}$ Securities and Futures Ordinance, s. 291(1)(a).

${ }^{54}$ Ibid., s. 291(1)(b).

${ }^{55}$ Ibid., s. 285(2).
} 
Securities (Insider Dealing) Ordinance] was to eliminate insider dealing and to reinforce the transparency of the markets, thereby enhancing and preserving Hong Kong's position as an international financial centre. ${ }^{56}$

In one particularly serious case, HKSAR v Du Jun, the offender was sentenced to six years imprisonment and fined $\$ 1688000 .{ }^{57} \mathrm{Du}$ Jun, a managing director of the fixed income department of Morgan Stanley, profited HK\$23.3 million after trading HK\$87.1 million worth of a stock over several months on inside information. In addressing the proper approach to sentencing in these matters, the Court of Appeal stated, "[i]t is not a mere soundbite to talk of the importance of the integrity of this particular market. It is a selfevident importance not devalued by the fact that the point is so often made." 58

In addition to insider dealing, market misconduct proceedings can also be brought for false trading, ${ }^{59}$ price rigging, ${ }^{60}$ disclosure of information about prohibited transactions, ${ }^{61}$ disclosure of false or misleading information inducing transactions, ${ }^{62}$ and stock market manipulation. ${ }^{63}$

\section{Anti-money Laundering and Anti-terrorist Financing Regime}

It is well known how money laundering activities can pose risks to financial institutions and markets and attract criticisms from the Financial Action Task Force. Hong Kong takes these risks seriously and has had anti-money laundering laws, in respect of drug trafficking proceeds, as early ago as $1989 .{ }^{64}$ In 1994 , a new law was enacted to address the proceeds of all indictable offences, ${ }^{65}$ and in 1995 , both laws were modernized to their current form. ${ }^{66}$

\footnotetext{
${ }^{56}$ Koon Wing Yee v Insider Dealing Tribunal (2008) 11 HKCFAR 170, [45].

${ }^{57}$ HKSAR v Du Jun [2012] 6 HKC 119 (CA).

${ }^{58}$ Ibid., [158].

${ }^{59}$ Securities and Futures Ordinance, s. 295. For more, see Mak (2015), ch 12.

${ }^{60}$ Ibid., s. 296.

${ }^{61}$ Ibid., s. 297.

62 Ibid., s. 298

${ }^{63}$ Ibid., s. 299.

${ }^{64}$ Drug Trafficking (Recovery of Proceeds) Ordinance (Cap. 405), originally Ord. 35 of 1989 (hereinafter "DTROPO").

${ }^{65}$ Organized and Serious Crimes Ordinance (Cap. 455), originally Ord. 82 of 1994 (hereinafter “OSCO”).

${ }^{66}$ See Drug Trafficking (Recovery of Proceeds) (Amendment) Ordinance 1995, Ord. 89 of 1995; Organized and Serious Crimes (Amendment) Ordinance 1995, Ord. 90 of 1995.
} 
The post-September $11^{\text {th }}$ terrorist financing legislation was enacted in $2002 .{ }^{67}$ In 2011 , a new regulatory system was enacted to deal more broadly with money laundering and terrorist financing risks to financial institutions. ${ }^{68}$

There are two general money laundering offences. The less serious one requires everyone who suspects certain property to be the proceeds or instruments of an indictable offence to report their suspicion to the police. ${ }^{69}$ The more serious money laundering offence involves dealing with property, while knowing or having reasonable grounds to believe the property is the proceeds of an indictable offence. ${ }^{70}$ Making a report to the police of suspected property (or intending to make such a report) can be a defense to the more serious charge under certain circumstances. $^{71}$

Courts have noted the risk posed by money laundering to the integrity of financial systems. In a leading sentencing decision on this offence, the Court of Appeal made reference to Hong Kong's IFC status in questioning whether the maximum sentence of 14 years imprisonment was sufficient for the offence of money laundering:

Given the number of cases that have come before the courts, given the huge sums involved in quite a few of them, given that laundering the proceeds of offences often very serious offences indeed - is designed by its very nature to enable criminals to avoid detection, and given the signal importance of preserving Hong Kong's reputation as an international financial centre of integrity, and given the further vital importance of international cooperation in the fight against money laundering, and therefore against crime which is thereby encouraged, the question whether the maximum sentence available to the courts of this jurisdiction is one that is adequate is a matter upon which we have not deliberated but it may merit some debate and consideration by policymakers. ${ }^{72}$

\footnotetext{
${ }^{67}$ United Nations (Anti-Terrorism Measures) Ordinance (Cap. 575), originally Ord. 27 of 2002. See also subsidiary legislation to the United Nations Sanctions Ordinance (Cap. 537), which implement the many United Nations Security Council resolutions binding on Hong Kong.

${ }^{68}$ Anti-Money Laundering and Counter-Terrorist Financing (Financial Institutions) Ordinance (Cap. 615), originally Ord. 15 of 2011.

${ }^{69}$ DTROPO, s. 25A; OSCO, s. 25A [both liable to 3 months imprisonment].

${ }^{70}$ DTROPO, s. 25; OSCO, s. 25 [both liable to 14 years imprisonment].

${ }^{71}$ DTROPO, ss. 25(2), 25A(2); OSCO, ss. 25(s), 25A(2).

${ }^{72}$ HKSAR v Boma Amaso, supra note 43, [31].
} 


\section{Corruption and Bribery Laws}

Since 1974, Hong Kong's Independent Commission Against Corruption has made great progress in lowering the level of corruption in both the public and private sectors. However, the circumstances of the Kwong Hing and Semtech International Holdings cases in the early 2000 s, both of which involved payments to equity research analysts to write favourable reports on companies, reminded us of the vulnerability of financial markets to corruption and bribery. $^{73}$

Hong Kong's Prevention of Bribery Ordinance, enacted in 1970, contains a comprehensive set of offences to address both public and private bribery. The offence commonly used in private bribery cases is known as "corrupt transactions with agents" ${ }^{74}$ It requires proof that an agent solicited or accepted an "advantage" as an inducement to or reward for "or otherwise on account of his" doing or having done any act in relation to his principal's affairs or business. ${ }^{75}$ It is also a crime for anyone to offer an advantage to an agent in a similar way. ${ }^{76}$ The principal's permission, lawful authority and reasonable excuse are available defenses. ${ }^{77}$ Advantage is defined broadly to include any gift, loan, fee, reward, commission, office, contract, payment, service, favour, exercise of any right and more, but excludes "entertainment", which is defined as "the provision of food or drink, for consumption on the occasion when it is provided, and of any other entertainment connected with, or provided at the same time as, such provisions". ${ }^{78}$

\section{Role of the Criminal Sanction}

The traditional role of the criminal sanction is to censure and punish blameworthy conduct that harms or threatens harm to a particular community. ${ }^{79}$ The punishment can serve different purposes, depending on the circumstances of the case. Those purposes include protecting the public, denouncing the offence, deterring others, and compensating victims.

\footnotetext{
${ }^{73}$ HKSAR v Li Man Tak, unreported, CACC303/2005, 13 Sept 2006, CA; HKSAR v Leung Chi Wah Earnest, unreported, CACC275/2007, 23 Oct 2008, CA.

${ }_{74}^{74}$ Prevention of Bribery Ordinance (Cap. 201), s. 9 [liable to 7 years imprisonment].

${ }^{75}$ Ibid., s. 9(1)(a). Forbearing to do an act is also captured.

${ }^{76}$ Ibid., s. 9(2).

${ }^{77}$ Ibid., s. 9(1), (2) \& (4).

${ }^{78}$ Ibid., s. 2(1).

${ }^{79}$ von Hirsch (1993).
} 
In the IFC context, the criminal sanction continues to play its traditional role but in a more limited fashion. Its role is limited by a number of factors. First, constitutional human rights law requires criminal proceedings to have certain safeguards and protections that make resort to criminal process more restrictive and risky than civil processes. Civil processes too punitive will be deemed to be criminal. Second, the human rights implications of criminal law and process have led to the development of various non-criminal enforcement measures that help to further the purposes of deterrence, compliance, compensation and public protection without need to rely upon the criminal sanction. Third, the Prosecutions Division of the Department of Justice decides the cases to be prosecuted in the higher criminal courts, and have generally been measured in their approach. Fourth, courts have generally interpreted criminal law offences narrowly and insisted upon clear moral culpability requirements, thereby keeping the net of criminal liability constrained. For all these reasons, the criminal sanction in the context of Hong Kong's IFC has primarily played only its traditional role of punishing and deterring serious cases.

The criminal sanction has an important secondary role in the IFC context. This is to back up coercive measures that promote disclosure and investigation. This secondary role highlights the importance of transparency and access to information in ensuring the integrity of an IFC.

\section{A. Primary Role: To Punish and Censure Serious Wrongdoing}

From July 2013 to July 2014, only about 17 per cent of all persons subject to enforcement measures under the SFO were prosecuted. ${ }^{80}$ Non-criminal measures, such as civil proceedings, disciplinary proceedings, or Market Misconduct Tribunal proceedings, accounted for the other enforcement cases. As of 31 December 2014, there was a drop of 67.3 per cent in criminal charges laid (year-on-year), while persons subject to ongoing civil proceedings increased by 31.9 per cent. ${ }^{81}$ In its statement of "enforcement philosophy", the SFC mentions its use of a range of enforcement measures to achieve three aims: punishment (“Justly punish wrongdoers for their misconduct"), deterrence ("Deter wrongdoers from repeating the misconduct and warn other market participants against mimicking similar

\footnotetext{
${ }^{80} \mathrm{SFC}(2014)$.

${ }^{81}$ SFC (2015b), p. 9.
} 
misconduct") and remediation ("Ensure that the consequences of wrongdoing are remedied by wrongdoers and their accomplices"). ${ }^{82}$ In practice, criminal prosecution serves mainly the punishment aim and to a limited extent the deterrence aim.

There are a number of reasons for why the criminal sanction has not played a more expansive role in the IFC context, notwithstanding the wishes of the SFC. Human rights law provisions, which operate on the constitutional level, have had considerable impact on the scope and application of the criminal sanction since 1991. Articles 10 and 11 of the Hong Kong Bill of Rights set out a set of minimum fair trial standards, which all criminal proceedings must guarantee. The more important fair trial rights include the presumption of innocence, the right to examine witnesses, and the right to silence (also known as the right against compelled self-incrimination). While these guarantees are important for protecting criminal defendants, they also make prosecutions more restrictive and challenging.

Human rights law also penetrates punitive legal processes disguised as a civil process. The Insider Dealing Tribunal (IDT) under the previous securities legislation was intended to be a strong civil process with powers to order penalties but without the trappings of the criminal process. In a 2008 decision of the CFA, Koon Wing Yee v Insider Dealing Tribunal, it was held that the IDT proceedings were criminal in nature because of the severity of the penalty power. ${ }^{83}$ If the tribunal was to keep its sanctions power, it had to adhere to criminal process standards including the prohibition on the use of compelled self-incriminatory evidence. Rather than declaring all IDT proceedings involving the use of compelled selfincriminatory evidence as being unconstitutionally unfair, the Court struck down the penalty provision to restore the original intent behind the IDT of being a civil process.

The Court's remedial compromise in Koon Wing Yee reflected the policy decisions implemented in the 2002 legislation. Those who drafted the SFO were aware of the human rights problem of the IDT and thus created a MMT that did not have the same severe penalty provision. In the words of Lord Hoffmann NPJ, "in recognition of the fact that criminal prosecutions for market misconduct are often dilatory, expensive and unpredictable, the Ordinance created the alternative of proceedings before the MMT" ${ }^{84}$ It was also recognised that a comprehensive range of criminal and non-criminal measures was needed to achieve the legislative aims. Criminal law and process could not be expected to be the normal vehicle to

\footnotetext{
${ }^{82}$ SFC (2013a).

${ }^{83}$ Koon Wing Yee v Insider Dealing Tribunal, supra note 56.

${ }^{84}$ Securities and Futures Commission v Tiger Asia Management LLC (2013) 16 HKCFAR 324, [21].
} 
serve the multiple purposes of enforcement. In a 2010 speech, the SFC's Director of Enforcement stated that the "traditional enforcement approach [...] to identify and prosecute the wrongdoer" was not sufficient and the SFC was "deeply engaged in not only sending deterrent messages [...] but also in remedying the consequences of securities market fraud and misconduct". ${ }^{85} \mathrm{He}$ explained that the SFC's approach was "to employ the full spectrum of remedies, both criminal and civil, not only to send deterrent messages but also to bring the law to bear on resolving the consequences of misconduct". 86

The MMT is an administrative tribunal that adjudicates upon misconduct proceedings instituted by the SFC. The tribunal, presided over by a judge and two other members, has wide powers to receive and consider evidence. Individuals are to be given a reasonable opportunity of being heard but the standard of proof of balance of probabilities is applicable. The Secretary for Justice must consent to all proceedings before they can be instituted before the MMT. The MMT can make a wide range of orders to promote the aims of deterrence, public protection and compensation. By order of the MMT, persons can be prohibited from being a director, liquidator, receiver or manager of a listed corporation, from acquiring or otherwise dealing in any securities, futures or leveraged foreign exchange contract for up to five years and from repeating conduct constituting market misconduct. Persons can also be ordered to pay the Government any profit gained or loss avoided, to pay costs and expenses reasonably incurred by the Government, SFC or Financial Reporting Council (as and where applicable), and to be recommended for disciplinary action by any applicable body. Failure to comply with prohibitive orders is an offence punishable up to HK\$1 million and 2 years imprisonment. Courts have rejected constitutional challenges to the MMT, reaffirming its non-criminal character. Its powers have been described as "protective rather than punitive in character" ${ }^{87}$ It has been said that the MMT decides neither criminal nor civil liability. Justice Andrew Cheung described its unique character in these terms:

It does not oust the jurisdiction of the criminal courts in Hong Kong, nor does it usurp their function. It is established to perform a regulatory and protective role in Hong Kong's financial markets. It is there to ensure that those engaged in market

\footnotetext{
${ }^{85}$ Steward (2010), p. 1-2.

${ }^{86}$ Ibid., p. 2.

${ }^{87}$ Luk Ka Cheung v The Market Misconduct Tribunal [2009] 1 HKLRD 114, [53] (CA). See also Chau Chin Hung v Market Misconduct Tribunal, unreported, HCAL123/2007, 22 Sept 2008, CFI, [84] \& [102].
} 
misconduct do not profit from their wrongs. In a fairly general sense, it performs a function that protects and benefits the interests of the society as a whole. But it does not determine criminal guilt nor impose penal sanction. Certainly it wields extensive powers and indeed it must act judicially. But one thing it does not do is to exercise the judicial power of the HKSAR. Hong Kong has a long history of using administrative bodies and tribunals for similar functions. ${ }^{88}$

Part IX of the SFO provides for various disciplinary actions to be brought by the SFC against regulated persons, including registered institutions. Where a person is "guilty of misconduct" or regarded as "not a fit and proper person", the SFC may revoke or suspend the person's licence or approval, publicly or privately reprimand the person, prohibit applications or approvals from being made for a period of time and order a pecuniary penalty not exceeding the greater of $\mathrm{HK} \$ 10$ million or three times the amount of any profit gained or loss avoided.

The SFO also provides for civil proceedings to be brought in relation to various kinds of misconduct to enable victims to more easily obtain compensation for losses. The use of section 213 as a civil enforcement tool by the SFC has given rise to litigation and commentary. ${ }^{89}$ Section 213 allows the SFC to apply for various orders where a person has contravened any relevant provision of the SFO. The orders can be far reaching including injunctive orders to restrain or prohibit continued breaches, orders to freeze property, orders to appoint administers of property, orders to declare contracts void, orders to secure compliance with other orders, and any necessary ancillary orders. In Securities and Futures Commission v Tiger Asia Management LLC, the CFA held that section 213 orders could be sought and made for market misconduct whether or not civil or criminal proceedings for such conduct had been or would be brought. ${ }^{90}$ It is a stand-alone enforcement provision that serves purposes different from those served by criminal and MMT proceedings. Lord Hoffmann NPJ wrote,

In these proceedings the SFC acts not as a prosecutor in the general public interest but as protector of the collective interests of the persons dealing in the market who have been injured by market misconduct. Proceedings under s 213 are the public law

\footnotetext{
${ }^{88}$ Luk Ka Cheung, ibid., [68].

${ }^{89}$ See Low, Datwani \& Datwani (2012).

${ }^{90}$ Securities and Futures Commission v Tiger Asia Management LLC, supra note 84.
} 
analogue of actions for damages by individuals under s 305 rather than a substitute for a criminal prosecution or proceedings before the MMT. They are plainly civil proceedings and therefore do not attract the protection accorded to criminal defendants. $^{91}$

In late February 2015, the SFC obtained its first ever court order (pursuant to section 212 of the SFO) to wind up a Hong Kong-listed company, known as China Metal Recycling (Holdings) Limited, in the public interest. ${ }^{92}$

With the availability of court orders under sections 213 and 212, MMT proceedings, disciplinary proceedings, and other civil proceedings, criminal prosecution is far from the enforcement option of choice and can be reserved for serious cases. This appears to be the sentiment expressed in this excerpt of a speech by the SFC's Director of Enforcement:

The greatest antidote to fraud is uprooting it once discovered and remedying the consequences. Of course I am not ignoring the wrongdoer. But I am arguing that concentrating on the wrongdoing alone is not enough to maintain confidence, orderliness and fairness in our markets if it means the wrongdoing and the harm and damage it has caused remains unchecked and unremedied. [...]

This analysis means the prescription must include broad civil and criminal remedies to chase down assets and proceeds wherever they may be; to apply for remedial sanctions for the benefit of victims; to ensure those who assist in fraud and misconduct, including those who help to hide it from detection, are made to pay for the costs of rectification and finally the prosecution of perpetrators. ${ }^{93}$

As hinted in the Director's speech, the SFC would like to see more criminal prosecutions of market misconduct. However, the SFC and the DOJ have not seen eye to eye on the issue of criminal prosecution. This difference of views became apparent in August 2013, on the eve of a change in leadership in the office of the Director of Public Prosecutions (DPP). ${ }^{94}$ The

\footnotetext{
${ }^{91}$ Ibid., [16].

92 SFC (2015a).

${ }^{93}$ Steward, supra note 85 , p. 2-3.

${ }^{94}$ Buddle (2013a).
} 
SFC expressed concerns with too few market misconduct cases being prosecuted in the higher courts and the slow response from the DOJ on referred cases, which the SFC attributed to insufficient resources designated to SFC cases. ${ }^{95}$ The then DPP maintained that decisions not to prosecute in the higher courts were properly made and that his concerns with the SFC handling both investigative and prosecutorial roles were such as to call for the withdrawal of the prosecutorial role from the SFC. ${ }^{96}$ Based on enforcement statistics for the first half of 2014, there does not appear to be any relative increase in the number persons prosecuted for market misconduct, and taking into account the statistics in the second half, the trend is downwards. ${ }^{97}$

A final reason for the limited role of criminal prosecutions is the tendency of the CFA to interpret criminal offences strictly thereby keeping the net of criminal liability constrained. In practice this means cases must be evidentially strong before they will be brought to court, and sufficiently serious if they are to be brought before a higher court. Two recent cases on the money laundering offence from the CFA illustrate this tendency. In the first case, the CFA held that the meaning of "proceeds of an indictable offence" did not include legitimate money used in the commission of an indictable offence. ${ }^{98}$ In the second case, the CFA held that the mens rea element of "having reasonable grounds to believe" had to be applied from the standpoint of the defendant taking into account his beliefs, perceptions and evaluations and could only be satisfied if anyone looking at the circumstances from the defendant's standpoint "would so believe" the property was proceeds of an indictable offence. ${ }^{99}$ Both decisions took a narrower approach to the offence than that taken in lower courts since at least 1999.

Another illustration of the Court's strict approach to the criminal law was its application of the offence of false trading to a case of "matched trades" of derivative warrants. ${ }^{100}$ The two appellants were day traders who generated profits "simply by buying and selling warrants to one another". ${ }^{101}$ Profit resulted because "the total amount of rebates [offered by the issuer] paid to the appellants was greater than the transaction costs they incurred". ${ }^{102}$ The

\footnotetext{
95 SFC (2013b).

${ }^{96}$ Zervos (2013), p. 10; Buddle (2013b).

${ }^{97}$ SFC (2014); SFC (2015b).

${ }^{98}$ HKSAR v Li Kwok Cheung George (2014) 17 HKCFAR 319.

${ }^{99}$ HKSAR v Pang Hung Fai [2014] 6 HKC 487, [52] (CFA).

${ }^{100}$ Fu Kor Kuen Patrick v HKSAR (2012) 15 HKCFAR 524, [6].

${ }^{101}$ Ibid., [42].

102 Ibid.
} 
offence required proof of conduct done with the intention or recklessness of creating a false or misleading appearance of active trading in warrants. ${ }^{103}$ However, there was a defense if the defendants could prove on balance of probabilities that they did not have the purpose of creating a false or misleading appearance of active trading. ${ }^{104}$ Though the Court rejected the reverse onus challenge to this defense, it found that the defendants did satisfy the persuasive burden required for the defense. ${ }^{105}$ The Court disagreed with the trial court's factual findings on the issue of "purpose", describing them as "unconvincing". 106

\section{B. Secondary Role: Promoting Disclosure and Transparency}

The criminal sanction is also called upon to play a secondary role of supplying the teeth behind investigative powers or disclosure obligations that further transparency aims and promote the integrity of the financial system.

In the securities and anti-corruption contexts, the enforcement agencies are given exceptional investigative powers to gather evidence and compel individuals to provide information. These compulsory powers are backed up with criminal sanctions. The legislative wisdom to include immunity provisions that prohibit the use in criminal proceedings of information gathered from these compulsory powers has saved them from constitutional challenge. Courts have been supportive of these powers and have not imposed restrictions on the derivative use of compelled information or on use of the compelled information for nonhearsay impeachment purposes. ${ }^{107}$ The two money laundering offences, mentioned earlier, also work together to promote disclosures of suspicious transactions so as to provide more intelligence to the police for further investigation.

In the companies and securities contexts, there are many provisions aimed at promoting disclosure of accurate information to the regulators and/or the public. Disclosing or releasing

\footnotetext{
${ }^{103}$ Securities and Futures Ordinance, s. 295(1).

${ }^{104}$ Ibid., s. 295(7).

${ }^{105}$ Fu Kor Kuen Patrick, supra note 100, [96] \& [101].

${ }^{106}$ Ibid., [99].

${ }^{107}$ HKSAR v Lee Ming Tee (2001) 4 HKCFAR 133; A v The Commissioner of the Independent Commission Against Corruption (2012) 15 HKCFAR 362.
} 
Book chapter in Jiaxiang Hu, Matthias Vanhullebusch \& Andrew Harding (eds.), Finance, Rule of Law and Development in Asia: Perspectives from Singapore, Hong Kong and Mainland China (Leiden/Boston: Brill Academic Publishers, forthcoming 2015)

false or misleading information is punished by the criminal law sanction. These offences are essential to preserving the integrity and transparency of the financial system. ${ }^{108}$

\section{Conclusion}

Although the criminal law is an essential aspect of the legal environment sustaining Hong Kong's IFC status, it plays only a limited enforcement role given the availability of a variety of non-criminal enforcement measures. It plays its traditional role of censuring and punishing serious blameworthy conduct that threatens property rights, economic interests or the integrity of financial systems. It is also well suited to play a secondary role in backing up investigative powers or disclosure duties to ensure a high rate of compliance. But going much beyond these roles, as the Hong Kong experience suggests, would not be wise. This is what appears to have happened with the prosecutor's use of the money laundering offence. The CFA has now reigned in the net of criminal liability for money laundering. The time is now ripe, following the example of the SFO, for a policy response that explores greater use of non-criminal measures to address money laundering risk outside the confines of financial institutions.

\footnotetext{
${ }^{108}$ For an illustration of one of such case, see To Shu Fai v Securities and Futures Commission (2009) 12 HKCFAR 758.
} 
References

Bibliography

Buddle, Cliff (2013a) “Top Prosecutor Kevin Zervos Calls for Curb on Legal Power of SFC," South China Morning Post, 17 August.

Buddle, Cliff (2013b) "Regulator Accused Justice Department of Failing to Prosecute 'Serious' Cases,' South China Morning Post, 31 August.

Da Roza, Antonio \& Kevin Tang (2014) Companies (Winding-Up and Miscellaneous Provisions) Ordinance: Commentary and Annotations, Hong Kong: Sweet \& Maxwell.

Financial Services Bureau (2000) "Legislative Council Brief - Regulatory Reform for the Securities and Futures Market - The Securities and Futures Bill," 10 November 2000, http://www.sfc.hk/web/doc/EN/legislation/securities/others/fsb-legco-be.pdf (accessed 29 April 2015).

Jackson, Michael (2003) Criminal Law in Hong Kong, Hong Kong: Hong Kong University Press.

Law Reform Commission of Hong Kong (LRCHK) (1996) Report on Creation of a Substantive Offence of Fraud, Hong Kong: LRCHK.

Legal Policy Division, Department of Justice, (1998) "Information Paper - Creation of a Substantive Offence of Fraud - Theft (Amendment) Bill 1998," LC Paper No. CB(2) 633/98-99(03), November 1998.

Legislative Council (LegCo) Secretariat (1999) "Report of the Bills Committee on Theft (Amendment) Bill 1998," LC Paper No. CB(2)2392/98-99, 28 June 1999.

Low, Chee Keong, Mohan Datwani \& Samantha Datwani (2012) "Pouncing Dragon, Hidden Tiger - A Case of Regulatory Overreach?” 42 Hong Kong Law Journal 701-16. 
Mak, Bernard (2015) Securities Law in Hong Kong, Hong Kong: LexisNexis.

Securities and Futures Commission (SFC) (2000) "The Securities and Futures Bill," http://www.sfc.hk/web/doc/EN/speeches/public/s\&fbill-broc.pdf (accessed 29 April 2015).

SFC (2013a) "Enforcement Philosophy," 5 March 2013, http://www.sfc.hk/web/EN/regulatory-functions/enforcement/enforcementphilosophy.html (accessed 29 April 2015).

SFC (2013b) "SFC statement on prosecutorial responsibility," 30 August 2013, http://www.sfc.hk/edistributionWeb/gateway/EN/news-andannouncements/news/corporate-news/doc?refNo=13PR86 (accessed 29 April 2015)

SFC (2014) "Persons Subject to Ongoing or Concluded Enforcement Proceedings - Quarterly Figures for Periods Ended 30 June 2014, 31 March 2014, 31 Dec 2013 and 30 Sept 2013,” http://www.sfc.hk/web/EN/regulatory-functions/enforcement/enforcementstatistics/people-subject-to-ongoing-or-concluded-enforcement-proceedings.html (accessed 29 April 2015).

SFC (2015a) "SFC Obtains Court Order to Wind up China Metal Recycling (Holdings) Limited," 26 February 2015, http://www.sfc.hk/edistributionWeb/gateway/EN/news-andannouncements/news/enforcement-news/doc?refNo=15PR18 (accessed 29 April 2015).

SFC (2015b) “Quarterly Report: October - December 2014," February 2015, http://www.sfc.hk/web/EN/files/ER/Reports/QR/201410-12/Eng/00_final.pdf (accessed 29 April 2015).

Steward, Mark (2010) "SFC Enforcement and Fraud - Speech at Conference on Fraud Risk Management," 24 May 2010, http://www.sfc.hk/web/doc/EN/speeches/speeches/10/Mark_20100524.pdf (accessed 29 April 2015).

von Hirsch, Andrew (1993) Censure and Sanctions, Oxford: Clarendon Press.

Young, Simon N.M. (2006) "Defending White Collar Crime in Hong Kong: A Case Study of the Lee Ming Tee Case.” 36 Hong Kong Law Journal 35-60.

Zervos, Kevin (2013) “Director's Overview," In Department of Justice, ed., Yearly Review of the Prosecutions Division 2012, Hong Kong: Department of Justice, 6-12.

Cases 
Book chapter in Jiaxiang Hu, Matthias Vanhullebusch \& Andrew Harding (eds.), Finance, Rule of Law and Development in Asia: Perspectives from Singapore, Hong Kong and Mainland China (Leiden/Boston: Brill Academic Publishers, forthcoming 2015)

A $v$ The Commissioner of the Independent Commission Against Corruption (2012) 15 HKCFAR 362.

Chan Fat Chu Raymond v HKSAR (2009) 12 HKCFAR 775.

Chau Chin Hung v Market Misconduct Tribunal, unreported, HCAL123/2007, 22 Sept 2008, CFI.

Fu Kor Kuen Patrick v HKSAR (2012) 15 HKCFAR 524.

HKSAR v Boma Amaso [2012] 2 HKLRD 33 (CA).

HKSAR v Du Jun [2012] 6 HKC 119 (CA).

HKSAR v Hill Wong, unreported, CACC329/2006, 4 July 2007, CA.

HKSAR v Hsu Ming Mei [2013] 1 HKLRD 286 (CA).

HKSAR v Leung Chi Wah Earnest, unreported, CACC275/2007, 23 Oct 2008, CA.

HKSAR v Lee Ming Tee (2001) 4 HKCFAR 133.

HKSAR v Li Kwok Cheung George (2014) 17 HKCFAR 319.

HKSAR v Li Man Tak, unreported, CACC303/2005, 13 Sept 2006, CA.

HKSAR v Pang Hung Fai [2014] 6 HKC 487 (CFA).

HKSAR v Pike James Edward, unreported, CACC486/2006, 9 August 2007, CA.

HKSAR v Tarazona Edgar Henry, unreported, CACC508/2002, 21 May 2013, CA.

HKSAR v Telephone Est (HK) Company Ltd [2014] 1 HKC 197 (CFI).

HKSAR v Wong Cho Sum [2001] 3 HKLRD 76 (CA).

HKSAR v Woo Mei Bo Mable, unreported, CACC565/2002, 15 Aug 2003, CA.

In Re Commission Ordinance, unreported, HCMP3039/1992, 8 Jan 1993, HC.

Koon Wing Yee v Insider Dealing Tribunal (2008) 11 HKCFAR 170.

Luk Ka Cheung v The Market Misconduct Tribunal [2009] 1 HKLRD 114 (CA).

Mo Yuk Ping v HKSAR (2007) 10 HKCFAR 386.

The Queen v Lee Tsat Pin, unreported, CACC315/1985, 19 Dec 1985, CA.

$R v$ Ghosh [1982] QB 1053 at 1064 (CA).

$R v$ Hinks [2001] 2 AC 241 (HL).

Re Robin Potts QC, unreported, HCMP4108/1999, 23 Sept 1999, CFI.

Re Timothy Michael Lord QC, unreported, HCMP1397/2013, 16 Aug 2013, CFI.

Securities and Futures Commission v C.L. Management Services Limited, unreported, ESS3067/2013, 11 June 2014, Mag Crt.

Securities and Futures Commission v Tiger Asia Management LLC (2013) 16 HKCFAR 324. 
Book chapter in Jiaxiang Hu, Matthias Vanhullebusch \& Andrew Harding (eds.), Finance, Rule of Law and Development in Asia: Perspectives from Singapore, Hong Kong and Mainland China (Leiden/Boston: Brill Academic Publishers, forthcoming 2015)

Tesco Supermarket Ltd v Nattrass [1972] AC 153 (HL).

To Shu Fai v Securities and Futures Commission (2009) 12 HKCFAR 758.

Legislation

Anti-Money Laundering and Counter-Terrorist Financing (Financial Institutions) Ordinance (Cap. 615).

Basic Law of the Hong Kong Special Administrative Region of the People's Republic of China, adopted by the $7^{\text {th }}$ National People's Congress at its $3^{\text {rd }}$ Session on 4 April 1990.

Companies Ordinance (Cap. 622).

Companies (Winding Up and Miscellaneous Provisions) Ordinance (Cap. 32).

Crimes Ordinance (Cap. 200).

Drug Trafficking (Recovery of Proceeds) (Amendment) Ordinance 1995, Ord. 89 of 1995.

Drug Trafficking (Recovery of Proceeds) Ordinance (Cap. 405).

Organized and Serious Crimes (Amendment) Ordinance 1995, Ord. 90 of 1995.

Organized and Serious Crimes Ordinance (Cap. 455).

Prevention of Bribery Ordinance (Cap. 201).

Securities and Futures Ordinance (Cap. 571).

Theft Ordinance (Cap. 201).

United Nations (Anti-Terrorism Measures) Ordinance (Cap. 575).

United Nations Sanctions Ordinance (Cap. 537). 